\title{
Wybrane aspekty doświadczania bólu przez pacjentów po zabiegu cholecystektomii
}

\author{
Selected aspects of pain experienced by patients after \\ cholecystectomy
}

GAWARKIEWICZ PAULINA ${ }^{1}$, ŚLUSARZ ROBERT²

${ }^{1}$ Nowy Szpital w Świeciu

${ }^{2}$ Instytut Nauk o Zdrowiu, PWSZ we Włocławku

DOI: http://dx.doi.org/10.21784//wP.2017.015

ISSN: 2451-1846

\section{Streszczenie:}

Wstęp. Cholecystektomia jest to zabieg polegający na usunięciu pęcherzyka żółciowego. Wykonywany jest techniką laparoskopową albo tradycyjną po otwarciu powłok brzusznych. Zabiegowi towarzyszy ból, który powstaje jako efekt zadziałania bodźców uszkadzających tkankę.

Cel. Celem pracy jest analiza wybranych aspektów bólu pooperacyjnego u pacjentów po zabiegu cholecystektomii.

Materiał i metody. Badania przeprowadzono wśród pacjentów w 1 dobie po zabiegu cholecystektomii, hospitalizowanych w oddziale chirurgii ogólnej. Zastosowano metodę szacowania i sondażu diagnostycznego, technikę skali szacunkowej i ankietowanie. Wykorzystane narzędzia badawcze to skala VAS, skala Laitinena oraz kwestionariusz ankiety własnej.

Wyniki. Odnotowano statystycznie istotną różnicę pomiędzy kobietami i mężczyznami jednie $\mathrm{w}$ zakresie czasu odczuwania bólu po cholecystektomii. Wiek i wykształcenie badanych pozostawały w istotnej statystycznie, średniej korelacji z wynikami czasu odczuwania bólu 
bezpośrednio po zabiegu. Mieszkańcy wsi znacznie częściej niż osoby mieszkające w mieście odczuwały całkowitą ulgę lub znaczne zmniejszenie dolegliwości po otrzymaniu preparatu przeciwbólowego.

Wnioski. Odczuwanie dolegliwości bólowych przez pacjentów po zabiegu cholecystektomii istotnie różni się w zależności od wybranych zmiennych socjodemograficznych.

Słowa kluczowe: cholecystektomia, ból, okres pooperacyjny

\begin{abstract}
Intoduction. Cholecystectomy is a procedure which consists in removing the gallbladder. It is performed by laparoscopic or traditional technique after opening the abdominal wall. The treatment is accompanied by pain, which arises as a result of the action of stimuli that damage the tissue.
\end{abstract}

Aim. The aim of the study is to analyze selected aspects of postoperative pain in patients after cholecystectomy.

Material and methods. The study was performed among patients 1 day after cholecystectomy, hospitalized in the general surgery ward. The method of estimation and diagnostic survey, estimation technique and questionnaire were used. The research tools used are the VAS scale, the Laitinena scale and the questionnaire survey.

Results. There was a statistically significant difference between men and women in terms of pain intensity after cholecystectomy. The age and education of the subjects were statistically significant, with a mean correlation with the results of pain intensity immediately after the procedure. Residents of the village much more often than people living in the city felt complete relief or significant reduction of ailments after receiving an analgesic.

Conclusions. The pain experienced by patients after cholecystectomy varies significantly depending on selected sociodemographic variables.

Keywords: cholecystectomy, pain, postoperative period

\title{
Wstęp
}


Ból jest to zjawisko psychiczne, ale również somatyczne. Według definicji Międzynarodowego Towarzystwa Badania Bólu jest to nieprzyjemne, subiektywne odczucie emocjonalne i zmysłowe powstające na skutek zadziałania bodźców uszkadzających tkankę [1]. Towarzyszy m.in. zabiegom chirurgicznym związanym z przerwaniem ciągłości skóry, tkanek, narządów.

Cholecystektomia jest to zabieg polegający na usunięciu pęcherzyka żółciowego. Wykonywany jest techniką laparoskopową albo tradycyjną po otwarciu powłok brzusznych przez cięcie przezprostne prawe lub pośrodkowe [2].

Śródoperacyjne uszkodzenie tkanek bądź narządów powoduje powstanie bólu pooperacyjnego. Jego intensywność i zasięg są najczęściej proporcjonalne do rozległości zabiegu [3]. Różnice osobnicze w odpowiedzi na doznania bólowe wynikają z wieku, płci, uwarunkowań genetycznych i kulturowych. Intensywność odczuwania bólu zależy także od wcześniejszych doświadczeń w tym zakresie, odczuć emocjonalnych i ogólnego stanu zdrowia człowieka. Ból najsilniej odczuwany jest przez pacjentów w pierwszej i drugiej dobie pooperacyjnej. Jego źródłem mogą być tkanki powierzchniowe: skóra, tkanka podskórna oraz tkanki głębokie: otrzewna, opłucna, stawy [1]. Do czynników wypływających na ból pooperacyjny należą (poza wiekiem, płcią pacjentów) rodzaj operacji, przygotowanie przedoperacyjne i cechy osobowości człowieka [4].

Celem pracy jest analiza wybranych aspektów bólu pooperacyjnego u pacjentów po zabiegu cholecystektomii.

\section{Materiał i metody}

W aktualnej pracy zastosowano metodę szacowania i sondażu diagnostycznego, technikę skali szacunkowej i ankietowanie. Wykorzystane narzędzia badawcze to skala VAS (Visual Analogue Scale), skala Laitinena oraz kwestionariusz ankiety własnej. Kwestionariusz ankiety własnej składał się z metryczki oraz 12 pytań, które dotyczyły charakterystyki doznań bólowych pacjenta. Skala VAS 
jest to wizualna skala analogowa za pomocą, której pacjent okres swój ból w granicach od 0-10, gdzie 0 oznacza brak bólu, a 10 ból nie wytrzymania [1]. Skala Laitinena służy do oceny bólu za pomocą czterech wskaźników (intensywności bólu, częstotliwości występowania bólu, ograniczenia aktywności fizycznej i stosowania leków przeciwbólowych). Każdą kategorię oblicza się oddzielnie i można ocenić od 0-4 punktów. Łączny wynik wskazuje na natężenie dolegliwości bólowych [5].

Badania przeprowadzono wśród pacjentów w 1 dobie pooperacyjnej po zabiegu cholecystektomii, hospitalizowanych w oddziale chirurgii ogólnej. Zgodę na przeprowadzenie badań uzyskano od Dyrekcji Nowego Szpitalu w Świeciu oraz Komisji Bioetycznej, działającej przy Collegium Medium w Bydgoszczy. Badania miały charakter dobrowolny, bezpłatny. Pacjenci zostali zapoznani z ich celem a po uzyskaniu od nich świadomej zgody na udział w badaniu, wypełnili samodzielnie kwestionariusz. Następnie została przeprowadzona ocena bólu pooperacyjnego na podstawie skali VAS i Laitinena.

Wyniki badań zostały następnie poddane analizie statystycznej. W analizie opisowej otrzymanych wyników zastosowano tabele, w których przedstawiono liczebność i procent. Obliczono również średnią wraz z odchyleniem standardowym. Współzależność pomiędzy dwiema zmiennymi, obliczono za pomocą współczynnik korelacji $\mathrm{R}$ Spearmana. Zastosowano również, nieparametryczny Test U Manna-Whitneya, do oceny różnic jednej cechy pomiędzy dwoma populacjami (grupami). Przyjęto $\mathrm{p} \leq 0,05$ jako poziom istotny statystycznie. Wszystkie obliczenia i ryciny wykonano arkuszem kalkulacyjnym Microsoft Excel i Statistica 10.0

W badaniach brało udział 60 osób (100\%). Liczniejszą grupę stanowiły kobiety - 43 osoby $(71,7 \%)$, w porównaniu do mężczyzn17 osób (28,3\%). Średnia wieku badanych to niespełna 53 lata. Odchylenie standardowe wyniosło ponad 28,7\% wartości średniej, co świadczy o znacznym zróżnicowaniu wiekowym. Starszymi okazali 
się mężczyźni, ze średnią wieku ponad 50 lat, przy średniej wieku w grupie kobiet - niespełna 51 lat. Wiek minimalny zbliżony, niższy w grupie kobiet wynosił 23 lata. Natomiast wiek maksymalny zróżnicowany, wyższy w grupie kobiet wynosił 88 lat. Badanych podzielono na cztery grupy wiekowe: do 40 lat, 41-55 lat, 56-65 lat oraz powyżej 65 lat. Najliczniejszą grupę stanowili respondenci w wieku 41-55 lat - 17 osób (28,3\%). Z kolei najmniej liczną osoby w wieku powyżej 65 lat - 13 osób $(21,7 \%)$. Liczniejszą grupę stanowili badani zamieszkujący wieś - 34 osoby $(56,7 \%)$ a mieszkańcami miasta było 26 osoby (43,3\%). Najliczniejszą grupę stanowili badani z wykształceniem średnim - 26 osób $(43,3 \%)$. Najmniej liczną grupą byli respondenci $\mathrm{z}$ wykształceniem podstawowym i wyższym - po 7 osób (po 11,7\%). Natomiast grupę z wykształcenie zawodowych stanowili- 20 osób $(33,3 \%)$.

\section{Wyniki}

W grupie pacjentów biorących udział w badaniu ponad połowa posiadała doświadczenia związane $\mathrm{z}$ hospitalizacją, $\mathrm{w}$ związku $\mathrm{z}$ koniecznością wykonania $\mathrm{w}$ przeszłości zabiegu operacyjnego (41 osób -68,3\%). Natomiast 19 osób (31,7\%) nie miało wcześniej przeprowadzanych operacji.

W związku z aktualną hospitalizacją ból po zabiegu cholecystektomii odczuwała ponad połowa badanych - 36 osób $(60,0 \%)$ a tylko 24 osoby (40\%) nie zgłaszały takich dolegliwości. W tabeli 1 przedstawiono czas odczuwania bólu przez badanych po operacji.

Tabela 1. Czas odczuwania bólu przez badanych po cholecystektomii. 


\begin{tabular}{|l|l|l|}
\hline czas & N & $\%$ \\
\hline $0-2 \mathrm{~h}$ & 33 & 55,0 \\
\hline $2-4 \mathrm{~h}$ & 17 & 28,3 \\
\hline $4-6 \mathrm{~h}$ & 5 & 8,3 \\
\hline $6-8 \mathrm{~h}$ & 5 & 8,3 \\
\hline Razem & 60 & 100,0 \\
\hline
\end{tabular}

Źródło: wynik badań własnych.

Najwięcej badanych odczuwało dolegliwości bólowe w ciągu dwóch pierwszych godzin po operacji - 33 osoby $(55,0 \%)$ oraz po $2-4$ godzinach od zabiegu (17 osób - 28,3\%). Natomiast odpowiednio po 5 pacjentów (8,3\%) zgłaszało ból po upływie 4-6 godzin oraz 6-8 godzin po zabiegu operacyjnym.

Zdecydowanie najczęściej nasilenie odczuwanego bólu po operacji respondenci oceniali jako średnie (28 osób -46,7\%). Natomiast 1 osoba $(1,7 \%)$ określiła te dolegliwości jako nie do zniesienia. Z kolei 14 osób (23,3\%) oceniło nasilenie bólu jako duże, a 17 badanych $(28,3 \%)$ jako małe.

Najwięcej badanych wskazało, że środek przeciwbólowy otrzymało w czasie 2 godzin po zabiegu - 46 osób (76,7\%). Natomiast po 2 - $4 \mathrm{~h}$ preparat przeciwbólowy podano 12 osobom (20\%). Najmniej badanych - odpowiednio po 1 osobie $(1,7 \%)$, otrzymało lek po 4-6 godzinach lub 6-8 godzin po operacji. Zdecydowana większość pacjentów nie musiała prosić pielęgniarki o podanie środka przeciwbólowego (46 osób -76,7\%). Natomiast 14 osób (23,3\%) było zmuszonych do zwrócenia się z taką prośbą.

Najwięcej badanych osób otrzymało lek przeciwbólowy drogą dożylną- 52 osoby $(86,7 \%)$. Natomiast 7 pacjentom (11,7\%) podano preparat przeciwbólowy drogą dożylną i podskórną. Jedna osoba 
$(1,7 \%)$ otrzymała leki wszystkimi wymienionymi wcześniej drogami podania.

Ponad połowa badanych stwierdziła, że po podaniu leku przeciwbólowego odczuła znaczną ulgę 33 osoby $(55,0 \%)$. Całkowita i umiarkowana ulga po podaniu leku dotyczyła 13 osób $(21,7 \%)$ natomiast niewielka - 1 osoby $(1,7 \%)$.

Zdecydowana większość badanych potwierdziła zminimalizowanie bólu przy otrzymaniu leku przeciwbólowego drogą dożylną - 58 osób (96,7\%). Natomiast po podaniu środka przeciwbólowego drogą podskórną potwierdziło ten fakt 6 osób (10\%). Tylko 1 osoba $(1,7 \%)$ odczuła ulgę w dolegliwościach po przyjęciu leku drogą doustną.

Ponad połowa badanych określiła nasilenie bólu po operacji podczas chodzenia jako średnie - 33 osoby $(55,0 \%), 13$ osób $(21,7 \%)$ jako małe a 11 pacjentów (18,3\%) jako duże. Z kolei dla 3 osób (5,0\%) ból podczas przemieszczania się był nie do zniesienia. Najwięcej badanych (22 osoby - 36,7\%), określiło nasilenie dolegliwości bólowych podczas kaszlu jako średnie a 19 osób (31,7\%) jako duże. Natomiast 1 osoba (1,7\%) nie odczuwała w takiej sytuacji dyskomfortu. Największy odsetek badanych odczuwał średnie nasilenie bólu podczas zmiany pozycji w łóżku - 27 osób (45,0\%). Z kolei 22 osoby $(26,7 \%)$ oceniło te dolegliwości jako duże a 10 osób (16,7\%) jako małe. Dla 1 osoby $(1,7 \%)$ nasilenie bólu podczas zmiany pozycji w łóżku było nie do zniesienia. $\mathrm{W}$ tabeli 2 zaprezentowano różnice dotyczące wybranych aspektów doświadczania bólu przez chorych po zabiegu cholecystektomii w zależności od płci badanych.

Tabela 2. Różnice dotyczące wybranych aspektów doświadczania bólu przez pacjentów po zabiegu cholecystektomii w zależności od ich płci. 


\begin{tabular}{|c|c|c|c|c|c|c|c|c|c|c|}
\hline 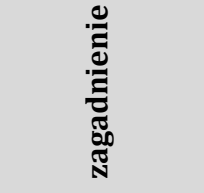 & 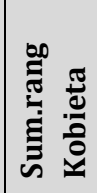 & 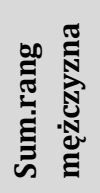 & D & $\mathbf{N}$ & 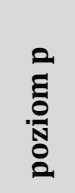 & N & 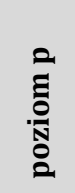 & 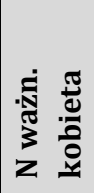 & 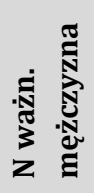 & 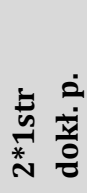 \\
\hline $\begin{array}{l}\text { wcześniejsze } \\
\text { operacje }\end{array}$ & $\begin{array}{l}1293, \\
0\end{array}$ & 537,0 & \begin{tabular}{|l}
347 \\
0
\end{tabular} & $\begin{array}{l}- \\
0,295\end{array}$ & $\begin{array}{l}0,76 \\
8\end{array}$ & $-0,366$ & $\begin{array}{l}0,71 \\
4\end{array}$ & 43 & 17 & 0,770 \\
\hline $\begin{array}{l}\text { odczuwanie } \\
\text { bólu } \\
\text { bezpośrednio } \\
\text { po zabiegu }\end{array}$ & $\begin{array}{l}1215, \\
5\end{array}$ & 614,5 & $\begin{array}{l}269 \\
5\end{array}$ & $\begin{array}{l}- \\
1,567\end{array}$ & $\begin{array}{l}0,11 \\
7\end{array}$ & $-1,846$ & $\begin{array}{l}0,06 \\
5\end{array}$ & 43 & 17 & 0,116 \\
\hline $\begin{array}{l}\text { czas } \\
\text { odczuwania } \\
\text { bólu po } \\
\text { zabiegu }\end{array}$ & $\begin{array}{l}1201, \\
0\end{array}$ & 629,0 & $\begin{array}{l}255, \\
0\end{array}$ & $\begin{array}{l}- \\
1,805\end{array}$ & $\begin{array}{l}0,07 \\
1\end{array}$ & $-2,005$ & $\begin{array}{l}0,04 \\
5\end{array}$ & 43 & 17 & 0,071 \\
\hline $\begin{array}{l}\text { odczuwane } \\
\text { nasilenie bólu }\end{array}$ & $\begin{array}{l}1365, \\
0\end{array}$ & 465,0 & $\begin{array}{l}312, \\
0\end{array}$ & 0,869 & $\begin{array}{l}0,38 \\
5\end{array}$ & 0,936 & $\begin{array}{l}0,34 \\
9\end{array}$ & 43 & 17 & 0,388 \\
\hline $\begin{array}{l}\text { czas } \\
\text { otrzymania } \\
\text { środka } \\
\text { przeciwbólowe } \\
\text { go po zabiegu }\end{array}$ & $\begin{array}{l}1308, \\
0\end{array}$ & 522,0 & $\begin{array}{l}362, \\
0\end{array}$ & - & $\begin{array}{l}0,96 \\
1\end{array}$ & $-0,067$ & $\begin{array}{l}0,94 \\
7\end{array}$ & 43 & 17 & 0,961 \\
\hline $\begin{array}{l}\text { konieczność } \\
\text { poproszenia } \\
\text { pielęgniarki o } \\
\text { środek } \\
\text { przeciwbólowy }\end{array}$ & $\begin{array}{l}1312, \\
5\end{array}$ & 517,5 & $\begin{array}{l}364 \\
5\end{array}$ & 0,008 & $\begin{array}{l}0,99 \\
3\end{array}$ & 0,011 & $\begin{array}{l}0,99 \\
1\end{array}$ & 43 & 17 & 0,987 \\
\hline $\begin{array}{l}\text { odczuwanie } \\
\text { ulgi po podaniu } \\
\text { środka } \\
\text { przeciwbólowe } \\
\text { go }\end{array}$ & $\begin{array}{l}1244, \\
0\end{array}$ & 586,0 & $\begin{array}{l}298, \\
0\end{array}$ & $\begin{array}{l}- \\
1,099\end{array}$ & $\begin{array}{l}0,27 \\
2\end{array}$ & $-1,219$ & $\begin{array}{l}0,22 \\
3\end{array}$ & 43 & 17 & 0,275 \\
\hline $\begin{array}{l}\text { odczuwanie } \\
\text { nasilenia bólu } \\
\text { podczas } \\
\text { chodzenia }\end{array}$ & $\begin{array}{l}1266, \\
0\end{array}$ & 564,0 & $\begin{array}{l}320 \\
0\end{array}$ & $\begin{array}{l}- \\
0,738\end{array}$ & $\begin{array}{l}0,46 \\
0\end{array}$ & $-0,817$ & $\begin{array}{l}0,41 \\
4\end{array}$ & 43 & 17 & 0,464 \\
\hline $\begin{array}{l}\text { odczuwanie } \\
\text { nasilenia bólu } \\
\text { podczas kaszlu }\end{array}$ & $\begin{array}{l}1284, \\
5\end{array}$ & 545,5 & $\begin{array}{l}338, \\
5\end{array}$ & $\begin{array}{l}- \\
0,435\end{array}$ & $\begin{array}{l}0,66 \\
4\end{array}$ & $-0,458$ & $\begin{array}{l}0,64 \\
7\end{array}$ & 43 & 17 & 0,661 \\
\hline $\begin{array}{l}\text { odczuwanie } \\
\text { nasilenia bólu } \\
\text { podczas } \\
\text { zmiany pozycji }\end{array}$ & $\begin{array}{l}1324, \\
5\end{array}$ & 505,5 & $\begin{array}{l}352, \\
5\end{array}$ & 0,205 & $\begin{array}{l}0,83 \\
8\end{array}$ & 0,222 & $\begin{array}{l}0,82 \\
5\end{array}$ & 43 & 17 & 0,833 \\
\hline
\end{tabular}


w łóżku

Źródło: wynik badań własnych.

Ze względu na poziom istotności $(\mathrm{p}<0,05)$, odnotowano statystycznie istotną różnicę pomiędzy kobietami i mężczyznami jednie w zakresie czasu odczuwania bólu po cholecystektomii. W tabeli 3 zaprezentowano charakterystykę zgłaszania dolegliwości bólowych przez pacjentów w zależności od ich płci.

Tabela 3. Czas odczuwania bólu przez badanych po cholecystektomii w zależności od ich płci.

\begin{tabular}{|l|l|l|l|l|}
\hline płeć & \multicolumn{2}{|l|}{ kobieta } & \multicolumn{2}{l|}{ mężczyzna } \\
\hline czas odczuwania bólu & N & $\%$ & N & $\%$ \\
\hline $0-2$ h & 27 & 62,8 & 6 & 35,3 \\
\hline $2-4$ h & 11 & 25,6 & 6 & 35,3 \\
\hline $4-6$ h & 2 & 4,7 & 3 & 17,6 \\
\hline $6-8$ h & 3 & 7,0 & 2 & 11,8 \\
\hline Razem & 43 & 100,0 & 17 & 100,0 \\
\hline
\end{tabular}

Źródło: wynik badań własnych.

W kolejnych godzinach po cholecystektomii, niezależnie od płci pacjentów, nasilenie bólu podlegało zmniejszeniu. Zdecydowanie najczęściej ból w pierwszych dwóch godzinach po operacji zgłaszały kobiety (27 osób -62,8\%), w porównaniu do mężczyzn (6 osób 35,3\%). Z kolei utrzymywanie się dolegliwości w późniejszym okresie pooperacyjnym częściej zgłaszali mężczyźni niż kobiety. Ból w kolejnych 2-4 godzinach po cholecystektomii potwierdziło 35,3\% 
mężczyzn (6 osób), w porównaniu do 25,6\% kobiet (11 osób). Dolegliwości po 4-6 godzinach wskazało 17,6\% mężczyzn (3 osoby) i 4,7\% pacjentek (2 osoby). Natomiast ból po kolejnych 6-8 godzinach podało 11,8\% mężczyzn ( 2 osoby) i 7,0\% kobiet ( 3 osoby). W tabeli 4 przedstawiono korelację wieku badanych i wybranych aspektów bólu w okresie pooperacyjnym.

Tabela 4. Korelacja wieku badanych i wybranych aspektów bólu w okresie pooperacyjnym.

\begin{tabular}{|c|c|c|c|c|}
\hline Zagadnienie & $\mathrm{N}$ & $\mathrm{R}$ & $t(N-2)$ & poziom $\mathrm{p}$ \\
\hline wcześniejsze operacje & 60 & $-0,042$ & $-0,318$ & 0,752 \\
\hline $\begin{array}{l}\text { odczuwanie bólu bezpośrednio po } \\
\text { zabiegu }\end{array}$ & 60 & 0,150 & 1,157 & 0,252 \\
\hline czas odczuwania bólu po zabiegu & 60 & 0,400 & 3,327 & 0,002 \\
\hline odczuwane nasilenie bólu & 60 & $-0,094$ & $-0,718$ & 0,476 \\
\hline $\begin{array}{l}\text { czas otrzymania środka } \\
\text { przeciwbólowego po zabiegu }\end{array}$ & 60 & $-0,008$ & $-0,062$ & 0,951 \\
\hline $\begin{array}{|lrr|}\begin{array}{l}\text { konieczność } \\
\text { pielęgniarki }\end{array} & \text { o } & \text { poproszenia } \\
\text { przeciwbólowy } & & \\
\end{array}$ & 60 & 0,148 & 1,141 & 0,259 \\
\hline $\begin{array}{l}\text { odczuwanie ulgi po podaniu środka } \\
\text { przeciwbólowego }\end{array}$ & 60 & 0,048 & 0,365 & 0,717 \\
\hline $\begin{array}{l}\text { odczuwanie nasilenia bólu podczas } \\
\text { chodzenia }\end{array}$ & 60 & $-0,314$ & $-2,519$ & 0,015 \\
\hline $\begin{array}{l}\text { odczuwanie nasilenia bóli podczas } \\
\text { kaszlu }\end{array}$ & 60 & $-0,123$ & $-0,943$ & 0,350 \\
\hline $\begin{array}{l}\text { odczuwanie nasilenia bólu podczas } \\
\text { zmiany pozycji w łóżku }\end{array}$ & 60 & $-0,180$ & $-1,396$ & 0,168 \\
\hline
\end{tabular}

Źródło: wynik badań własnych. 
Wiek badanych, pozostawał $\mathrm{w}$ istotnej statystycznie, średniej korelacji z wynikami czasu odczuwania bólu bezpośrednio po zabiegu oraz odczuwaniem nasilenia bólu podczas chodzenia $(p<0,05)$. W tabeli 5. zaprezentowano czas odczuwania bólu po cholecystektomii przez badanych w zależności od ich wieku.

Tabela 5. Czas odczuwania bólu przez badanych po cholecystektomii w zależności od ich wieku.

\begin{tabular}{|l|l|l|l|l|l|l|l|l|}
\hline wiek & \multicolumn{2}{|l|}{ do 40 lat } & \multicolumn{2}{l|}{$41-55$ lat } & \multicolumn{2}{l|}{$56-65$ lat } & \multicolumn{2}{l|}{ powyżej 65} \\
lat
\end{tabular}

Źródło: wynik badań własnych.

Najsilniejsze dolegliwości niezależnie od wieku zgłaszali pacjenci w ciągu dwóch pierwszych godzin po cholecystektomii. Wyjątek stanowili respondenci powyżej 65 roku życia, gdzie tak silne natężenie bólu wystąpiło po 6-8 godzinach od operacji. Związane było to $\mathrm{z}$ uruchamianiem chorego.

W grupie wiekowej do 40 lat, zdecydowana większość badanych odczuwała ból po zabiegu w czasie dwóch pierwszych godzin - 12 osób (80,0\%). Tylko 3 osoby (20\%) wskazywały na utrzymywanie się bólu w czasie kolejnych 2-4 godzin.

W grupie wiekowej 41-55 lat, najwięcej osób zgłaszało dolegliwości w czasie 2 pierwszych godzin okresu pooperacyjnego - 
9 osób $(52,9 \%)$. Po upływie 4-6 godzin była to tylko 1 osoba $(5,9 \%)$. Natomiast 2-4 godziny od zabiegu dolegliwości bólowe zgłaszało 7 osób $(41,2 \%)$.

W grupie wiekowej 56-65 lat, najwięcej badanych odczuwało ból po zabiegu w czasie 2 godzin po cholecystektomii - 8 osób $(53,3 \%)$, a tylko 1 osoba $(6,7 \%)$ po 6-8 godzinach. Z kolei po upływie 2 - 4 godzin od operacji dolegliwości bólowych doświadczały 4 osoby $(26,7 \%)$ a po kolejnych 4-6 godzinach 2 osoby $(13,3 \%)$.

W grupie wiekowej powyżej 65 lat, największy odsetek pacjentów odczuwał ból po 22 godzinach oraz 6-8 godzin od operacji - po 4 osoby (po 30,8\%). Natomiast po upływie 2-4 godzin od zabiegu ból zgłaszały 3 osoby $(23,1 \%)$ a po $4-6$ godzinach -2 osoby $(15,4 \%)$. W tabeli 6. przedstawiono odczuwanie bólu po operacji przez badanych podczas chodzenia.

Tabela 6. Odczuwane bólu po cholecystektomii przez badanych podczas chodzenia.

\begin{tabular}{|l|l|l|l|l|l|l|l|l|}
\hline wiek & \multicolumn{2}{|l|}{ do 40 lat } & \multicolumn{2}{l|}{$41-55$ lat } & \multicolumn{2}{l|}{$56-65$ lat } & \multicolumn{2}{l|}{ powyżej } \\
\hline nasilenie bólu & $\mathrm{N}$ & $\%$ & $\mathrm{~N}$ & $\%$ & $\mathrm{~N}$ & $\%$ & $\mathrm{~N}$ & $\%$ \\
\hline małe & 0 & 0,0 & 2 & 11,8 & 5 & 33,3 & 6 & 46,2 \\
\hline średnie & 11 & 73,3 & 9 & 52,9 & 9 & 60,0 & 4 & 30,8 \\
\hline duże & 3 & 20,0 & 6 & 35,3 & 1 & 6,7 & 1 & 7,7 \\
\hline nie do zniesienia & 1 & 6,7 & 0 & 0,0 & 0 & 0,0 & 2 & 15,4 \\
\hline $\begin{array}{l}\text { nie odczuwałem/ am } \\
\text { żadnych dolegliwości } \\
\text { bólowych }\end{array}$ & 0 & 0,0 & 0 & 0,0 & 0 & 0,0 & 0 & 0,0 \\
\hline Razem & 15 & 100,0 & 17 & 100,0 & 15 & $\begin{array}{l}100, \\
0\end{array}$ & 13 & 100,0 \\
\hline
\end{tabular}

Źródło: wynik badań własnych. 
Żaden $\mathrm{z}$ respondentów nie potwierdził braku dolegliwości związanych z uruchamianiem. Z kolei ból towarzyszący chodzeniu jako nie do zniesienia określali najczęściej pacjenci po 65 roku życia. W grupie wiekowej do 40 lat, najwięcej badanych odczuwało ból w stopniu średnim - 11 osób $(73,3 \%)$. Tylko 1 osoba $(6,7 \%)$ podała, że był on nie do zniesienia. Natomiast 3 osoby (20\%) określały doznania bólowe jako duże. W grupie wiekowej 41-55 lat, najwięcej osób odczuwało ból w stopniu średnim 9 osób (52,9\%), najmniej w stopniu małym - 2 osoby $(11,8 \%)$. Natomiast 6 osób (35,3\%) określiło nasilenie bólu jako duże. W grupie wiekowej 56-65 lat, najwięcej badanych odczuwało ból w stopniu średnim - 9 osób $(60,0 \%)$, najmniej w stopniu dużym - 1 osoba (6,7\%). Z kolei 5 osób $(33,3 \%)$ określiło dolegliwości jako małe. W grupie wiekowej powyżej 65 lat, najwięcej osób odczuwało ból w stopniu małym - 6 osób $(46,2 \%)$, najmniej w stopniu dużym - 1 osoba $(7,7 \%)$. Pozostali badani ocenili swoje doznania bólowe - 4 osoby (30,8\%) jako średnie a 2 osoby $(15,4 \%)$ jako nie do zniesienia. W tabeli 7. zaprezentowano różnice dotyczące wybranych aspektów doświadczania bólu przez chorych po zabiegu cholecystektomii w zależności od ich miejsca zamieszkania.

Tabela 7. Różnice dotyczące wybranych aspektów doświadczania bólu przez pacjentów po zabiegu cholecystektomii w zależności od ich miejsca zamieszkania. 


\begin{tabular}{|c|c|c|c|c|c|c|c|c|c|c|}
\hline 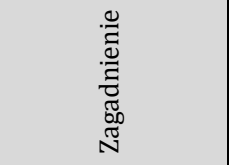 & 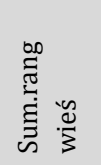 & 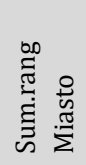 & $\triangleright$ & $N$ & 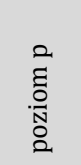 & N & 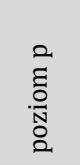 & 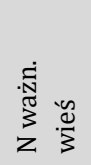 & 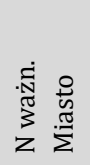 & 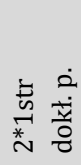 \\
\hline $\begin{array}{l}\text { wcześniejsze } \\
\text { operacje }\end{array}$ & 1074,0 & 756,0 & 405,0 & 0,544 & 0,586 & 0,676 & 0,499 & 34 & 26 & 0,589 \\
\hline $\begin{array}{l}\text { odczuwanie bólu } \\
\text { bezpośrednio po } \\
\text { zabiegu }\end{array}$ & 929,0 & 901,0 & 334,0 & $-1,604$ & 0,109 & $-1,890$ & 0,059 & 34 & 26 & 0,109 \\
\hline $\begin{array}{l}\text { czas odczuwania } \\
\text { bólu po zabiegu }\end{array}$ & 1114,0 & 716,0 & 365,0 & 1,141 & 0,254 & 1,268 & 0,205 & 34 & 26 & 0,256 \\
\hline $\begin{array}{l}\text { odczuwane } \\
\text { nasilenie bólu }\end{array}$ & 1078,5 & 751,5 & 400,5 & 0,612 & 0,541 & 0,658 & 0,510 & 34 & 26 & 0,539 \\
\hline $\begin{array}{l}\text { czas otrzymania } \\
\text { środka } \\
\text { przeciwbólowego } \\
\text { po zabiegu }\end{array}$ & 1037,5 & 792,5 & 441,5 & 0,000 & 1,000 & 0,000 & 1,000 & 34 & 26 & 0,994 \\
\hline $\begin{array}{ll}\text { konieczność } & \\
\text { poproszenia } & \\
\text { pielęgniarki } \quad \text { o } \\
\text { środek } \\
\text { przeciwbólowy }\end{array}$ & 945,0 & 885,0 & 350,0 & $-1,365$ & 0,172 & $-1,863$ & 0,062 & 34 & 26 & 0,174 \\
\hline $\begin{array}{l}\text { odczuwanie ulgi } \\
\text { po podaniu } \\
\text { środka } \\
\text { przeciwbólowego }\end{array}$ & 912,0 & 918,0 & 317,0 & $-1,857$ & 0,063 & $-2,059$ & 0,039 & 34 & 26 & 0,063 \\
\hline $\begin{array}{l}\text { odczuwanie } \\
\text { nasilenia bólu } \\
\text { podczas } \\
\text { chodzenia }\end{array}$ & 1071,0 & 759,0 & 408,0 & 0,500 & 0,617 & 0,553 & 0,580 & 34 & 26 & 0,620 \\
\hline $\begin{array}{l}\text { odczuwanie } \\
\text { nasilenia bóli } \\
\text { podczas kaszlu }\end{array}$ & 1111,5 & 718,5 & 367,5 & 1,104 & 0,270 & 1,163 & 0,245 & 34 & 26 & 0,269 \\
\hline \begin{tabular}{l}
\multicolumn{2}{l}{ odczuwanie } \\
nasilenia bólu \\
podczas zmiany \\
pozycji w łóżku
\end{tabular} & 1103,5 & 726,5 & 375,5 & 0,985 & 0,325 & 1,065 & 0,287 & 34 & 26 & 0,324 \\
\hline
\end{tabular}

Źródło: wynik badań własnych.

Ze względu na poziom istotności $(\mathrm{p}<0,05)$, odnotowano statystycznie istotną różnicę pomiędzy mieszkańcami miasta i wsi, 
jedynie $\mathrm{w}$ zakresie odczuwania ulgi po podaniu środka przeciwbólowego. W tabeli 8. zaprezentowano w zależności od miejsca zamieszkania badanych odczuwanie przez nich ulgi po otrzymaniu środka przeciwbólowego.

Tabela 8. Odczuwanie ulgi przez badanych po podaniu środka przeciwbólowego $\mathrm{w}$ zależności od ich miejsca zamieszkania.

\begin{tabular}{|l|l|l|l|l|}
\hline miejsce zamieszkania & miasto & \multicolumn{3}{|l|}{ wieś } \\
\hline odpowiedź & $\mathrm{N}$ & $\%$ & $\mathrm{~N}$ & $\%$ \\
\hline całkowitą & 4 & 15,4 & 9 & 26,5 \\
\hline znaczną & 12 & 46,2 & 21 & 61,8 \\
\hline umiarkowaną & 10 & 38,5 & 3 & 8,8 \\
\hline niewielką & 0 & 0,0 & 1 & 2,9 \\
\hline brak & 0 & 0,0 & 0 & 0,0 \\
\hline Razem & 26 & 100,0 & 34 & 100,0 \\
\hline
\end{tabular}

Źródło: wynik badań własnych.

Mieszkańcy wsi znacznie częściej niż osoby mieszkające w mieście odczuwały całkowitą ulgę lub znaczne zmniejszenie dolegliwości po otrzymaniu preparatu przeciwbólowego. Po podaniu środka przeciwbólowego w grupie mieszkańców miasta, najwięcej badanych odczuwało ulgę znaczną - 12 osób (46,2\%), bądź umiarkowaną - 10 osób (38,5\%). Jedynie 4 osoby $(15,4 \%)$ wskazały na całkowite ustąpienie bólu. Wśród mieszkańców wsi po podaniu leku przeciwbólowego, najwięcej badanych odczuwało ulgę znaczną 21 osób (61,8\%), bądź całkowitą - 9 osób (26,5\%). Najmniej z kolei 
umiarkowane - 3 osoby $(8,8 \%)$ oraz niewielkie zniesienie dolegliwości - 1 osoba $(2,9 \%)$.

W tabeli 9. przedstawiono korelację wykształcenia badanych i wybranych aspektów bólu w okresie pooperacyjnym.

Tabela 9. Korelacje wykształcenia badanych i wybranych aspektów bólu w okresie pooperacyjnym.

\begin{tabular}{|c|c|c|c|c|}
\hline Zagadnienie & $\mathrm{N}$ & $\mathrm{R}$ & $t(N-2)$ & poziom $\mathrm{p}$ \\
\hline wcześniejsze operacje & 60 & $-0,171$ & $-1,322$ & 0,191 \\
\hline $\begin{array}{l}\text { odczuwanie bólu bezpośrednio po } \\
\text { zabiegu }\end{array}$ & 60 & $-0,042$ & $-0,319$ & 0,751 \\
\hline czas odczuwania bólu po zabiegu & 60 & $-0,338$ & $-2,736$ & 0,008 \\
\hline odczuwane nasilenie bólu & 60 & 0,163 & 1,260 & 0,213 \\
\hline $\begin{array}{l}\text { czas otrzymania środka } \\
\text { przeciwbólowego po zabiegu }\end{array}$ & 60 & $-0,050$ & $-0,379$ & 0,706 \\
\hline $\begin{array}{lrr}\text { konieczność } & & \text { poproszenia } \\
\text { pielęgniarki } & \text { o } & \text { środek } \\
\text { przeciwbólowy } & & \\
\end{array}$ & 60 & 0,021 & 0,157 & 0,876 \\
\hline $\begin{array}{l}\text { odczuwanie ulgi po podaniu środka } \\
\text { przeciwbólowego }\end{array}$ & 60 & 0,095 & 0,723 & 0,472 \\
\hline $\begin{array}{l}\text { odczuwanie nasilenia bólu podczas } \\
\text { chodzenia }\end{array}$ & 60 & 0,156 & 1,205 & 0,233 \\
\hline $\begin{array}{l}\text { odczuwanie nasilenia bóli podczas } \\
\text { kaszlu }\end{array}$ & 60 & 0,138 & 1,061 & 0,293 \\
\hline $\begin{array}{l}\text { odczuwanie nasilenia bólu podczas } \\
\text { zmiany pozycji w łóżku }\end{array}$ & 60 & 0,194 & 1,506 & 0,138 \\
\hline
\end{tabular}

Źródło: wynik badań własnych. 
Wykształcenie badanych, pozostawało $\mathrm{w}$ istotnej statystycznie, średniej korelacji z wynikami czasu odczuwania bólu przez pacjentów bezpośrednio po zabiegu $(\mathrm{p}<0,05)$.

W tabeli 10. przedstawiono czas odczuwania bólu przez badanych w zależności od ich wykształcenia.

Tabela 10. Czas odczuwania bólu przez badanych w zależności od ich wykształcenia.

\begin{tabular}{|l|l|l|l|l|l|l|l|l|}
\hline wykształcenie & \multicolumn{2}{|l|}{ podstawowe } & \multicolumn{2}{l|}{ zawodowe } & \multicolumn{2}{l|}{ średnie } & \multicolumn{2}{l|}{ wyższe } \\
\hline czas & N & $\%$ & $\mathrm{~N}$ & $\%$ & $\mathrm{~N}$ & $\%$ & $\mathrm{~N}$ & $\%$ \\
\hline $0-2 \mathrm{~h}$ & 2 & 28,6 & 8 & 40,0 & 18 & 69,2 & 5 & 71,4 \\
\hline $2-4 \mathrm{~h}$ & 3 & 42,9 & 7 & 35,0 & 5 & 19,2 & 2 & 28,6 \\
\hline $4-6 \mathrm{~h}$ & 1 & 14,3 & 2 & 10,0 & 2 & 7,7 & 0 & 0,0 \\
\hline $6-8 \mathrm{~h}$ & 1 & 14,3 & 3 & 15,0 & 1 & 3,8 & 0 & 0,0 \\
\hline Razem & 7 & 100,0 & 20 & 100,0 & 26 & 100,0 & 7 & 100,0 \\
\hline
\end{tabular}

Źródło: wynik badań własnych.

Niezależnie od wykształcenia badanych największe nasilenie bólu zgłaszali oni w ciągu pierwszych czterech godzin po operacji. W pierwszych 2 godzinach po zabiegu najczęściej potwierdzały dolegliwości osoby z wykształceniem średnim i wyższym. W grupie pacjentów z wykształceniem podstawowym, najwięcej badanych odczuwało ból w czasie 2-4 godzin po zabiegu - 3 osoby (42,9\%. Tylko po 1 osobie (po 14,3\%) odnotowano wśród chorych zgłaszających dolegliwości w czasie 4-6 godzin oraz 6-8 godzin po zabiegu - po 1 osobie). W okresie pierwszych dwóch godzin po cholecystektomii doznania bólowe zgłaszały 2 osoby $(28,6 \%)$. Wśród pacjentów z wykształceniem zawodowym, najwięcej osób odczuwało ból po 
zabiegu w czasie 2 godzin - 8 osób $(40,0 \%)$, najmniej w czasie kolejnych 4-6 godzin - 2 osoby (10,0\%). Po 2-4 godzinach ból zgłaszało 7 osób (35\%) a po 6 - 8 godzinach- 3 osoby (15\%). W grupie chorych z wykształceniem średnim, najwięcej badanych odczuwało ból po zabiegu w czasie 2 godzin - 18 osób (69,2\%) a tylko 1 osoba $(3,8 \%)$ w czasie kolejnych 6-8 godzin. Pozostali badani zgłaszali dolegliwości bólowe po operacji po upływie 2-4 godzin- 5 osób (19,2\%) oraz po 4-6 godzinach- 2 osoby $(7,7 \%)$. Wśród pacjentów z wykształceniem wyższym, najwięcej osób odczuwało ból po zabiegu w czasie 2 godzin - 5 osób (71,4\%), pozostali w czasie kolejnych 24 godzin -2 osoby $(28,6 \%)$.

\section{Dyskusja}

Współcześnie pomimo lepszego poznania mechanizmu bólu, stosowania złożonych metod terapii $\mathrm{w}$ dalszym ciągu wyniki badań z krajów europejskich potwierdzają niedostateczny poziom łagodzenia dolegliwości bólowych $\mathrm{w}$ okresie pooperacyjnym. Należy mieć na uwadze, że niewłaściwa kontrola bólu może prowadzić do szeregu negatywnych konsekwencji takich jak np. rozwój bólu przewlekłego, zakażeń, gorszego gojenia rany. To z kolei może wpływać na m.in. niższą ocenę satysfakcji chorych z udzielanych świadczeń, wydłużenie czasu hospitalizacji, wzrostu wzrost kosztów opieki i leczenia $[6,7,8]$.

Zalecenia Polskiego Towarzystwa Badania Bólu, Polskiego Towarzystwa Anestezjologii i Intensywnej Terapii dotyczące leczenia bólu $\mathrm{w}$ okresie pooperacyjnym, korespondujące $\mathrm{z}$ najnowszymi doniesieniami światowymi w tym zakresie, sugerują, aby terapia bólu w warunkach szpitalnych została zorganizowana w oparciu o funkcjonowanie Zespołu Leczenia Bólu (Acute Pain Service, APS). Skupia się on bowiem na zadaniach związanych $\mathrm{z}$ m.in. informowaniem pacjentów o możliwościach terapii przeciwbólowej po operacji, szkoleniem personelu medycznego, stosowaniem zasad leczenia bólu zgodnych $\mathrm{z}$ wytycznymi, monitorowaniem natężenia 
bólu. Spełnianie takich kryteriów umożliwia szpitalowi ubieganie się o certyfikat „Szpital bez Bólu”. Audyty w Wielkiej Brytanii związane z uzyskiwaniem tego certyfikatu przez jednostki dowiodły m.in. zmniejszenia odsetka pacjentów z silnymi dolegliwościami bólowymi, liczby powikłań $\mathrm{w}$ terapii bólu oraz przyczyniły się do zwiększenia zatrudnienia pielęgniarek zajmujących się bólem [8,9].

Z przeprowadzonych badań wynika, że ból po zabiegu cholecystektomii odczuwała ponad połowa chorych. Najwięcej pacjentów zgłaszało dolegliwości bólowe w ciągu dwóch pierwszych godzin po operacji oraz po 2-4 godzinach od zabiegu. Zdecydowanie najczęściej nasilenie odczuwanego bólu po operacji respondenci oceniali jako średnie lub duże. Niezależnie od wieku najsilniejsze dolegliwości zgłaszało najwięcej pacjentów w ciągu dwóch pierwszych godzin po cholecystektomii. Wyjątek stanowiły osoby powyżej 65 roku życia, gdzie podobny odsetek respondentów wskazywał na silne natężenie bólu po 6-8 godzinach od operacji, co mogło być związane m.in. $\mathrm{z}$ uruchamianiem chorego. $\mathrm{W}$ kolejnych godzinach po cholecystektomii, niezależnie od płci pacjentów, nasilenie bólu podlegało zmniejszeniu. Zdecydowanie najczęściej ból w pierwszych dwóch godzinach po operacji zgłaszały kobiety, w porównaniu do mężczyzn.. Z kolei utrzymywanie się dolegliwości w późniejszym okresie pooperacyjnym częściej dotyczyło mężczyzn niż kobiet.

Aktualne badania $\mathrm{z}$ uwagi na zmienne demograficzne dowodzą istotnych różnic jedynie $\mathrm{w}$ nielicznych aspektach związanych z odczuwaniem bólu $\mathrm{w}$ okresie pooperacyjnym przez chorych. W badaniach Jurczak A., Kiryk A. i wsp. nie wykazano istotnych zależności między odczuwaniem bólu pooperacyjnego, a takimi zmiennymi socjodemograficznymi, jak: płeć, wykształcenie, miejsce zamieszkania, aktywność zawodowa. Nasilenie dolegliwości bólowych było najsilniejsze $\mathrm{w}$ ciągu pierwszych 24 godzin po zabiegu i zmniejszało się $\mathrm{w}$ miarę upływu czasu. Stwierdzono zależność pomiędzy natężeniem bólu a wiekiem 180 pacjentów leczonych chirurgicznie. Nasilenie bólu było najsilniejsze w grupie respondentów 
w przedziale wiekowym do 40 lat [4]. Badania Kołodziej i Karpel prowadzone wśród 132 chorych po różnego typu zabiegach operacyjnych operacyjnym wykazały, że wiek, płeć i wykształcenie nie mają istotnie statystycznego wpływu na opisywane przez respondentów dolegliwości bólowe oceniane w drugiej i czwartej dobie po operacji. Niemniej jednak autorzy podkreślili, że osoby po 60 roku życia wskazywali na dłuższe w czasie utrzymywanie się bólu. Z kolei kobiety częściej deklarowały wyższe natężenie bólu w chwili badania. Ponadto wskazano, że pomimo stosowania leków przeciwbólowych ból dotyczył większości pacjentów w okresie pooperacyjnym a jego natężenie zmniejszało się w czasie [10].

\section{Wnioski}

1. Odnotowano statystycznie istotną różnicę pomiędzy kobietami i mężczyznami jednie w zakresie czasu odczuwania bólu po cholecystektomii. Zdecydowanie najczęściej ból w pierwszych dwóch godzinach po operacji zgłaszały kobiety, w porównaniu do mężczyzn. Z kolei utrzymywanie się dolegliwości w późniejszym okresie pooperacyjnym częściej zgłaszali mężczyźni niż kobiety.

2. Wiek badanych, pozostawał w istotnej statystycznie, średniej korelacji z wynikami czasu odczuwania bólu bezpośrednio po zabiegu oraz odczuwaniem nasilenia bólu podczas chodzenia.

3. Mieszkańcy wsi znacznie częściej niż osoby mieszkające w mieście odczuwały całkowitą ulgę lub znaczne zmniejszenie dolegliwości po otrzymaniu preparatu przeciwbólowego.

4. Wykształcenie badanych, pozostawało w istotnej statystycznie, średniej korelacji z wynikami czasu odczuwania bólu przez pacjentów bezpośrednio po zabiegu. 


\section{Zalecenia dla praktyki pielęgniarskiej}

W dążeniu do skutecznego uśmierzania bólu u pacjenta po zabiegu operacyjnym zadaniem pielęgniarki jest kontrolowanie jego natężenia w związku ze stosowaniem działań terapeutycznych i pielęgnacyjnych oraz usprawnianiem chorego. Niezbędne jest w tym celu korzystanie ze standaryzowanych narzędzi obrazowania bólu i radzenia sobie pacjentów $\mathrm{w}$ sytuacjach doświadczania dolegliwości bólowych.

\section{Bibliografia / Bibliography:}

1. Juda M. Rola pielęgniarki w zwalczaniu bólu pooperacyjnego. Pielęgniarstwo Polskie. 2015;3:333-336.

2. Ścisło L. Opieka nad pacjentem z wybranymi chorobami pęcherzyka żółciowego, dróg żółciowych i wątroby. [w:] Walewska E. (red.), Podstawy pielęgniarstwa chirurgicznego. Wyd. Lekarskie PZWL. Warszawa 2007; 304,424-431.

3. Wordliczek J., Dobrogowski J. Ból pooperacyjny i pourazowy. [w:] Wordliczek J., Dobrogowski J. (red.), Leczenie bólu. Wyd. Lekarskie PZWL, Warszawa 2013;263.

4. Jurczak A., Kiryk A., Kotwas A., Pawlik J, Celewicz A., Szkup M., Grochans E. Ocena jakości opieki pielęgnacyjnej w zakresie bólu pooperacyjnego. Family Medicine \& Primary Care Review. 2015;17(2):107-110.

5. Laitinen J. Acupuncture and transcutaneous electric stimulation in the treatment of chronic sacrolumbalgia and ischialgia. The American Journal of Chinese Medicine. 1976;4:169-175.

6. Oderda G. Challenges in the Management of Acute Postsurgical Pain. Pharmacotherapy. 2012;32(9 Pt 2):6S-11S. 
7. Allegri M., Grossi P. Management of postoperative pain: how accurate and successful is our acute pain management? Minerva Anestesiologica. 2012; 78(1):1-3.

8. Misiołek H., Cettler M., Woroń J., Wordliczek J., Dobrogowski J., MayznerZawadzka E.: Zalecenia postępowania w bólu pooperacyjnym AD 2014. Ból. 2014:15(3):22-50.

9. Duncan F., Day R., Haigh C., Gill S. First Steps Toward Understanding the Variability in Acute Pain Service Provision and the Quality of Pain Relief in Everyday Practice Across the United Kingdom. Pain Medicine. 2014;15: 142-153.

10. Kołodziej W., Karpel E. Ból pooperacyjny na oddziale chirurgicznym w ocenie ankietowanego badania z zastosowaniem kwestionariusza McGillaMelzacka- doniesienia wstępne, Problemy Pielęgniarstwa. Via Medica. 2008; 16(3):231-236. 